\title{
Pengaruh Gaji dan Insentif terhadap Kinerja Karyawan Bagian Produksi PT. Uniplastindo Interbuana Pandaan
}

\author{
Ike Ratnasari $^{1}$ \\ Ashadi Mahmud ${ }^{2}$ \\ Program Studi Manajemen \\ Sekolah Tinggi Imu Ekonomi KertanegaraMalang \\ ratnamnz.ir@gmail.com \\ ashadihrd@gmail.com
}

\begin{abstract}
This study aims to describe the effect of salary and incentives on the performance of employees of PT. Unilastindo Interbuana Pandaan simultaneously, partially and most dominantly. The method used in this study is a descriptive method with a quantitative approach, data analysis techniques that are validity, reliability, multiple linear regression with $F$ test and $t$ test. The validity test results obtained by the calculated $r$ value of the variable salary, incentives and employee performance is greater than the value of $r$ proven valid tables and the reliability test results obtained a reliable value of salary, incentives and proven reliable employee performance. Based on the results of the F test (Simultaneous), known the value of sig. $F$ count is 0.00 because the significance value of $F$ is less than 0.05 , the regression analysis model is significant. $T$ test results explain, that the salary and incentive variables significantly influence employee performance variables, because the salary is significant $0.018<0.05$ and the incentive is significant $0.012<0.05$. The most dominant incentive variable influences employee performance, this is indicated by the value of Standardized Coefficients Beta incentive variable is greater than the salary variable. Influenced by indicators include: performance, length of work, seniority, needs, fairness and eligibility, job evaluation.
\end{abstract}

Keywords: salary, incentives, employee performance

\begin{abstract}
Abstrak
Penelitian ini bertujuan untuk mendeskripsikan pengaruh gaji dn insentif terhadap kinerja karyawan bagian produksi PT. Unilastindo Interbuana Pandaan secara simultan, parsial dan paling dominan. Metode yang digunakan pada penelitian ini adalah metode deskriptif dengan pendekatan kuantitatif, teknik analisis data yaitu uji validitas, reliabilitas, regresi linier berganda dengan uji $\mathrm{F}$ dan uji t. Hasil uji validitas diperoleh nilai $r$ hitung dari variabel gaji, insentif dan kinerja karyawan lebih besar dari nilai $r$ tabel valid terbukti dan hasil uji reliabilitas diperoleh nilai reliabel gaji, insentif dan kinerja karyawan reliabel terbukti. Berdasarkan dari hasil uji $F$ (Simultan), diketahui nilai sig. $F$ hitung sebesar 0,00 karena nilai signifikansi $F$ kurang dari 0,05 maka model analisis regresi adalah signifikan. Hasil uji t menjelaskan, bahwa variabel gaji dan insentif berpengaruh signifikan terhadap variabel kinerja karyawan, karena gaji signifikan 0,018<0,05 dan insentif signifikan 0,012 < 0,05. Variabel insentif yang paling dominan berpengaruh terhadap kinerja karyawan, hal ini ditunjukkan dengan nilai Standardized Coefficients Beta variabel insentif lebih besar dibandingkan variabel gaji. Dipengaruhi indikator antara lain : kinerja, lama bekerja, senioritas, kebutuhan, keadilan dan kelayakan, evaluasi jabatan.
\end{abstract}

Kata Kunci: gaji, insentif, kinerja karyawan 


\section{PENDAHULUAN}

Seiring kemajuan ilmu pengetahuan dan teknologi, perkembangan industri dilndonesia saat ini berkembang sangat pesat. Dibuktikan dengan banyaknya perusahaan yang berdiri di Indonesia mulai dari perusahaan tekstil, alat berat, mesinmesin, bahan makanan dan minuman. Ketika industri saat ini semakin berkembang seiring kemajuan teknologi yang ada, maka peran sumber daya manusia dalam suatu perusahaan sangatlah penting. Karena sumber daya manusia tersebut merupakan kunci yang menentukan perkembangan perusahaan. Sumber daya manusia merupakan penggerak, pemikir dan perencana untuk mencapai tujuan perusahaan.Secara garis besar SDM merupakan individu yang bekerja sebagai penggerak suatu perusahaan dan berfungsi sebagai aset yang harus dilatih juga dikembangkan kemampuannya. Jika kemampuan SDM tidak dikembangkan, maka produktivitas perusahaan tidak akan maju, bahkan akan mengalami penurunan. Karena perkembangan ilmu pengetahuan dan teknologi maka mau tidak mau kita harus mengikuti perkembangan yang ada agar tidak tertinggal oleh perkembangan ilmu pengetahuan dan teknologi yang terus berkembang.

Perkembangan teknologi memicu persaingan antar satu perusahaan dengan perusahaan lain. Suatu perusahaan diharapkan dapat memiliki produktivitas yang baik, salah satunya adalah dengan adanya SDM yang baik dan berkualitas.Suatu perusahaandalam melaksanakan semua kegiatannya tidak terlepas dari peranan unsur manusia sebagai tenaga kerja. Tenaga kerja ini perlu mendapatkan perhatian khusus agar mereka menjadi tenaga yang berkualitas dan mencapai produktivitas yang optimal. Satu diantara usaha yang dilakukan agar tenaga kerja dapat menghasilkan produktivitas yang optimal adalah dengan memberikan gaji dan insentif yang memadai dari pihak perusahaan untuk menghasilkan kinerja yang baik.

Tingkat gaji yang masih sangat rendah akan mempengaruhi usaha peningkatan produktivitas karyawan,sebaliknya tingkat produktivitas yang sangat rendah sulit untuk menjamin naiknya gaji. Tinggi rendahnya gaji yang diterima oleh para karyawan sangat menentukan tinggi rendahnya tingkat kesejahteraan karyawan, dimana tingkat kesejahteraan karyawan besar pengaruhnya terhadap semangat mereka dalam melaksanakan aktivitas. Tinggi rendahnya gaji tergantung dari jabatan oleh seorang karyawan pada perusahaan,karena gaji merupakan daya pendorong bagi karyawan dalam mengembangkan bakat dan kemampuannya. Gaji yang sesuai akan membuat kinerja karyawan menjadi lebih baik dan memadai, sebaliknya ketika gaji tidak sesuai dengan yang diharapkan, maka kinerja karyawan juga akan buruk.

Pengukuran kinerja karyawan perlu dilakukan dalam memastikan pemahaman para pelaksana dan mengukur pencapaian prestasi. Memastikan tercapainya skema prestasi yang disepakatimemonitor, mengevaluasi kinerja dengan perbandingan antara skema kerja dan pelaksanaan. Memberikan penghargaan maupun hukuman yang obyektif atas prestasi pelaksanaan yang telah diukur sesuai sistem pengukuran yang telah disepakati, menjadikan sebagai alat komunikasi antara karyawan dan pimpinan dalam upaya memperbaiki kinerja perusahaan. Memastikan bahwa pengambilan keputusan dilakukan secara obyektif dan mengungkapkan permasalahan yang terjadi. Ukuran yang dipakai untuk menentukan kinerja perusahaan salah satunya adalah kinerja karyawan. Peningkatan kualitas sumber daya manusia di perusahaan dapat dilakukan dengan pendekatan peningkatan kualitas karyawan pada semua tingkatan. Kualitas karyawan yang semakin tinggi, diharapkan semakin tinggi 
juga kinerja perusahaan, sebaliknya semakin rendah kualitas karyawan semakin rendah pula kinerja perusahaan.

Menurut Hariandja (2009: 23), "Gaji merupakan bayaran tetap yang diterima seseorang dari keanggotaannya dalam sebuah organisasi". Selain itu dengan diberikannya insentif pada karyawan atau pegawai merupakan imbalan jasa yang diberikan perusahaan.Kinerja merupakan hasil kerja yang dicapai oleh individu yang disesuaikan dengan peran atau tugasnya yang dihubungkan dengan suatu ukuran nilai tertentu dari perusahaan dimana individu tersebut bekerja. Dalam penentuan kinerja, ada tiga indikator yang perlu diperhatikan, yaitu keterampilan yang meliputi kemampuan dan kecakapan individu, tingkat upaya yang diperlihatkan untuk menyelesaikan pekerjaan yang berkaitan dengan tugas karyawan, dan kondisi eksternal juga internal yang mendukung produktivitas karyawan. Hal ini menunjukan bahwa kinerja bergantung pada ketiga faktor tersebut, jika salah satu cukup atau tidak mendukung satu dengan yang lain maka kinerja akan terganggu.

Perusahaan memberikan gajidan insentif agar karyawan termotivasi untuk bekerja,gajidan insentif sangat menentukan untuk membuat orang mau bekerja. Karyawan melakukan pekerjaannya untuk mendapatkan gaji atau imbalan yang sesuai dengan pekerjaannya. Gaji adalah balas jasa yang dibayarkan kepada pekerjadengan berpedoman atas perjanjian kontrak kerja yang telah disepakati untuk metode pembayarannya. Sedangkan insentif merupakan alat untuk mendorong karyawan agar lebih meningkatkan produktivitas kerja untuk mencapai tujuan perusahaan yang telah ditetapkan. Insentifdapat diberikan dalam berbagai bentuk, yaitu berupa uang, lingkungan kerja yang baik dan partisipasi. Uang merupakan suatu yang penting diberikan sebagai perangsang, dengan memberi uang berarti memberi alat untuk merealisasikan kehidupan pegawai, hal ini dapat merangsang pegawai untuk selalu meningkatkan prestasi kerjanya.

\section{A. Kajian Pustaka}

Gaji (X1)

Gaji lebih banyak dipakai untuk pekerjaan-pekerjaan yang sifatnya tetap atau untuk pekerjaan yang mengikat, seperti pegawai bulanan, pegawai negeri ataupunpegawai tetap. Pengertian upah dan gaji memiliki hakekat yang sama, yaitu kedua- duanya menyangkut balas jasa terhadap prestasi seseorang.Untuk lebih jelasnya definisi gaji menurut para ahli antara lain sebagai berikut :Menurut Andrew F. Sikula $(2007 ; 119)$ dalam buku Manajemen Sumber Daya Manusia "Gaji adalah balas jasa dalam bentuk uang yang diterima karyawan sebagai konsekuensi dari statusnya sebagai seorang karyawan yang memberikan kontribusi dalam mencapai tujuan perusahaan". Menurut Sadili Samsudin $(2010 ; 189)$ dalam buku Manajemen Sumber Daya Manusia"Gaji adalah sesuatu yang berkaitan dengan uang yang diberikan kepada pegawai atau karyawan". Menurut Rivai $(2009 ; 360)$ mengatakan bahwa : Gaji merupakan balas jasa dalam bentuk uang yang diterima karyawan sebagai konsekuensi dari kedudukan sebagai karyawan yang memberikan sumbangan dan pikiran dalam mencapai tujuan perusahaan". 


\section{Indikator Gaji}

Kurniawati (2013:9) Indikator dari gajiadalah:

1) Kelayakan, gaji yang sesuai selalu di harapkan karyawan. Kinerja yang tinggi membuat karyawan mengharapkan gaji yang lebih begitupun tingkat usia dan lama bekerja, akan membuat karyawan selalu mengharapkan sebuah gaji yang layak dan sesuai dari perusahaan.

2) Motivasi Kerja, perasaan yang muncul jika menerima gaji membuat karyawan lebih bersemangat untuk bekerja, karyawan akan semangat dan meningkatkan kinerjanya.

3) Kepuasan Kerja, perasaan yang muncul jika karyawan menerima gaji berdasarkan faktor unik dalam diri mereka, seperti tingkat kinerja yang senioritas, karyawan akan merasa puas bahwa kinerja mereka sangat dihargai dan dibutuhkan dalam perusahaan.

\section{Insentif (X2)}

Insentif sebagai sarana motivasi yang mendorong para karyawan untuk bekerja dengan kemampuan yang optimal, yang dimaksudkan sebagai pendapatan ekstra di luar gaji atau upah yang telah ditentukan. Istilah sistem insentif pada umumnya digunakan untuk menggambarkan rencana-rencana pembayaran upah yang dikaitkan secara langsung atau tidak langsung dengan berbagai standar kinerja karyawan atau profitabilitas organisasi. Hasibuan (2011:118) "Insentif adalah tambahan balas jasa yang diberikan kepada karyawan tertentu yang prestasinya di atas prestasi standar". Upah insentif ini merupakan alat yang dipergunakan pendukung prinsip adil dalam pemberian kompensasi. Riani (2013:131) "Insentif adalah sarana untuk memotivasi karyawan dalam mencapai suatu target tertentu. Insentif dalam perkembanganya bisa dalam berbagai bentukbonus, komisi baik secara finansial (uang dan saham) ataupun dalam bentuk benefit lain (jalan-jalan keluar negeri, rumah, mobildan lain-lain)".

\section{Indikator Insentif}

Menurut Rivai (2009:388) Indikator yang mempengaruhi tingkat insentifkaryawan suatu organisasi, diantaranya:

1) Kinerja

Sistem insentif dengan cara ini langsung mengkaitkan besarnya insentif dengan kinerja yang telah ditunjukkan oleh pegawai yang bersangkutan. Berarti besarnya insentif tergantung pada banyak sedikitnya hasil yang dicapai dalam waktu kerja pegawai.

2) Lama Kerja

Besarnya insentif ditentukan atas dasar lamanya pegawai melaksanakan atau menyelesaikan suatu pekerjaan. Cara perhitungannya dapat menggunakan per jam, per hari, per mingguataupun per bulan. Umumnya cara yang diterapkan apabila ada kesulitan dalam menerapkan cara pemberian insentif berdasarkan kinerja. 
3) Senioritas

Sistem insentif ini didasarkan pada masa kerja atau senioritas pegawai yang bersangkutan dalam suatu organisasi. Dasar pemikirannya adalah pegawai senior, menunjukkan adanya kesetiaan yang tinggi dari pegawai yang bersangkutan pada organisasi dimana mereka bekerja. Semakin senior seorang pegawai semakin tinggi loyalitasnya pada organisasi.

4) Kebutuhan

Cara ini menunjukkan bahwa insentif pada pegawai didasarkan pada tingkat urgensi kebutuhan hidup yang layak dari pegawai. Ini berarti insentif yang diberikan adalah wajar, apabila dapat dipergunakan untuk memenuhi sebagian kebutuhan pokok tidak berlebihan namun tidak berkekurangan.

5) Keadilan dan Kelayakan

a. Keadilan

Dalam sistem insentif keadilan bukanlah harus sama rata tanpa pandang bulu, tetapi harus terkait pada adanya hubungan antara pengorbanan (input) dengan (output), makin tinggi pengorbanan semakin tinggi insentif yang diharapkan, sehingga yang harus dinilai adalah pengorbanannya yang diperlukan oleh suatu jabatan.

b. Kelayakan

Disamping masalah keadilan dalam pemberian insentif tersebut perlu pula diperhatikan masalah kelayakan. Layak pengertiannya membandingkan besarnya insentif dengan perusahaan lain yang bergerak dalam bidang usaha sejenis.

6) Evaluasi Jabatan

Evaluasi jabatan adalah suatu usaha untuk menentukan dan membandingkan nilai suatu jabatan tertentu dengan nilai jabatanlain dalam suatu organisasi. Ini berarti pula penentuan nilai relatif atau harga dari suatu jabatan guna menyusun rangking dalam penentuan insentif.

\section{Kinerja Karyawan (Y)}

Kinerja atau performance merupakan sebuah penggambaran mengenai tingkat pencapaian pelaksanaan suatu program kegiatan atau kebijakan dalam mewujudkan sasaran, tujuan, visi dan misi organisasi yang dituangkan dalam suatu perencanaan strategi suatu organisasi.Moeheriono (2009:60) "Kinerja karyawan adalah gambaran mengenai tingkat pencapaian pelaksanaan suatu program kegiatan atau kebijakan dalam mewujudkan sasaran, tujuan, visi dan misi organisasi yang dituangkan melalui perencanaan strategi suatu organisasi".Mangkunegara (2012:9) "Kinerja karyawan adalah hasil kerja secara kualitas dan kuantitas yang dicapai oleh seseorang karyawan dalam melaksanakan tugasnya sesuai dengan tanggung jawab yang diberikan kepadanya".Hasibuan (2012:94) "Kinerja karyawan adalah hasil kerja yang dicapai seseorang dalam melaksanakan tugas yang dibebankan kepadanya yang didasarkan atas kecakapan, pengalaman dan kesungguhan serta waktu". 


\section{Indikator Kinerja Karyawan}

Sulistiyanti (2009:228) Indikator kinerja karyawan yaitu sebagai berikut :

1) Prestasi kerja Hasil kerja karyawan baik kualitas maupun kuantitas, sesuai standar organisasi.

2) Disiplin kerja Kepatuhan karyawan terhadap ketentuan organisasi dan ketepatan waktu penyelesaian tugas atau pekerjaan sesuai standar waktu yang telah ditetapkan.

3) Efektivitas dan efisiensi kerja

Kemampuan memanfaatkan segala sumber daya organisasi secara tepat, sehingga tugas-tugas diselesaikan tepat waktu dan hasil maksimal.

4) Tanggung jawab

Kesiapan karyawan dalam mengembangkan tugas dan wewenang sesuai dengan jabatan yang dipangkunya, termasuk kesiapan menanggung segala akibat yang terjadi dari pekerjaannya.

5) Hubungan antar sesama

Kemampuan untuk memelihara hubungan yang harmonis antar sesama karyawan dan hubungan antar atasan dengan bawahan dalam rangka meningkatkan kerjasama.

\section{Kerangka Konseptual Penelitian}

Adapun kerangka pemikiran dalam penyusunan penelitian ini, dapat digambarkan dalam model sebagai berikut:

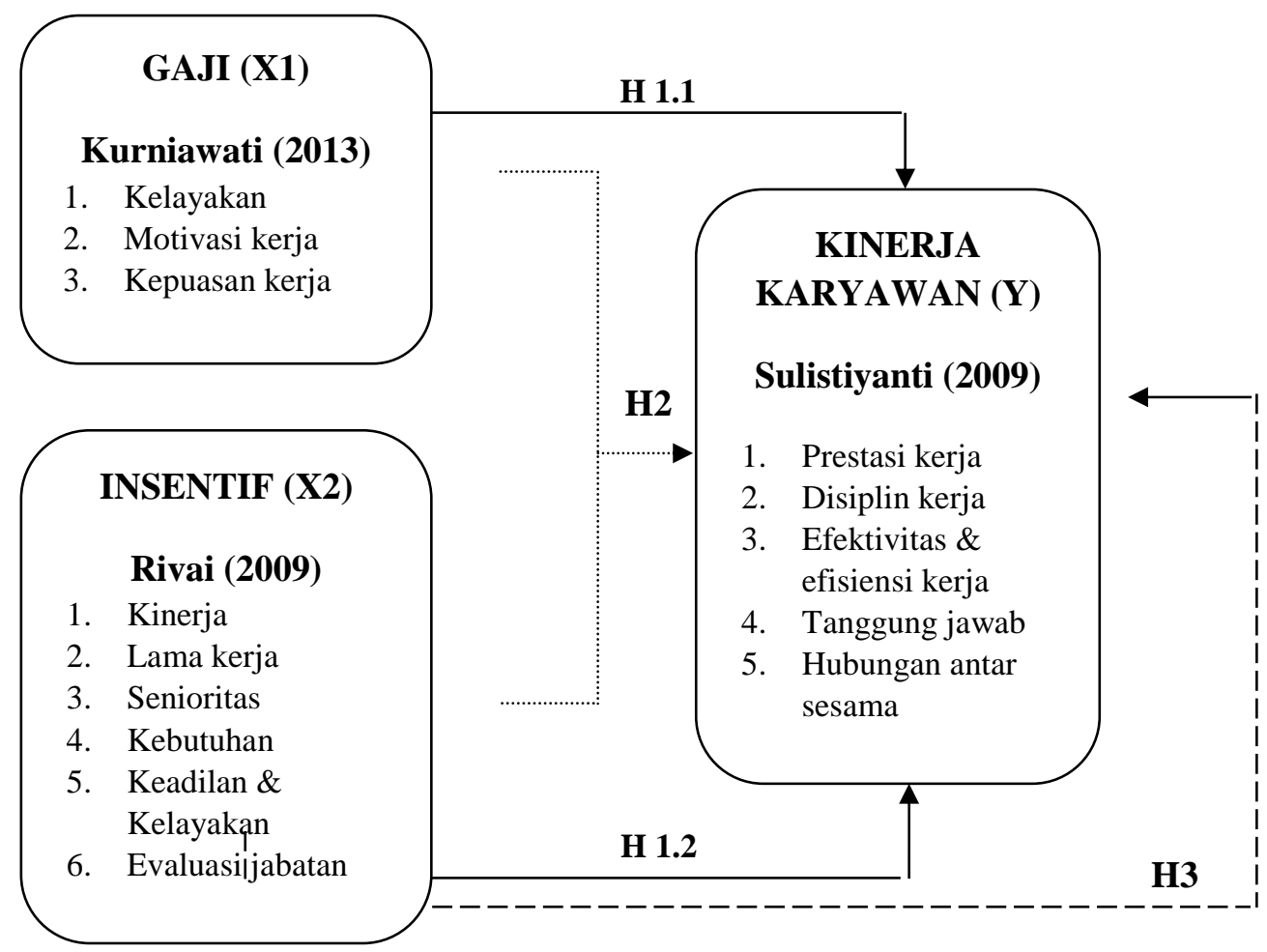

Gambar 1. Kerangka Konsep Penelitian

Sumber : Data Penelitian Diolah 
Keterangan :

Pengaruh secara Simultan

Pengaruh secara Parsial=

Pengaruh paling Dominan $\quad=\quad------$.

\section{Keterangan Hipotesis}

H1 =Diduga pengaruh antara gaji dan insentif terhadapkinerja karyawan bagian produksi PT. Uniplastindo Interbuana Pandaan secara parsial.

$\mathrm{H} 2$ =Diduga pengaruh antara gaji dan insentif terhadap kinerja karyawan bagian produksi PT. Uniplastindo Interbuana Pandaan secara simultan.

H3 =Diduga insentifpaling dominan berpengaruh terhadap kinerja karyawan bagian produksi PT. Uniplastindo Interbuana Pandaan paling dominan.

\section{METODE}

\section{A. Instrumen Penelitian}

Uji instrumen penelitian adalah uji pendahuluan yang berguna untuk mengetahui validitas dan realibitas data yang diperoleh dari tiap item kuesioner yang diisi responden. Menggunakan metode kuantitatif, diharapkan akan didapatkan hasil pengukuran yang akurat tentang respon yang diberikan responden, sehingga data yang berbentuk angka dapat diolah dengan menggunakan metode statistik. Instrumen pada penelitian ini adalah sebuah data primer berupa kuesioner yang disebarkan kepada responden atau karyawan PT. Uniplastindo Interbuana Pandaan bagian produksi. Hasil dari data yang didapat akan dianalisis menggunakan SPSS 25 for Windows.

\section{B. Populasi dan Teknik Pengambilan Sampel}

\section{1) Populasi}

Populasi adalah gabungan dari seluruh elemen yang berbentuk peristiwa hal atau orang yang memiliki karakteristik serupa menjadi pusat perhatian para peneliti, oleh karena itu dipandang sebagai sebuah semesta penelitian (Ferdinand: 2006). Adapun yang menjadi populasi dalam penelitian ini adalah karyawan pada PT. Uniplastindo Interbuana Pandaan, yang berjumlah 110 karyawan. Menurut Arikunto (2006) apabila subyeknya kurang dari 100, maka diambil semua sehingga penelitiannya merupakan penelitian populasi. Dari ketentuan tersebut populasi adalah karyawan PT. Uniplastindo Interbuana Pandaan yang berjumlah 110 karyawan.

2) Sampel

Sampel adalah sebagian dari jumlah dan karakteristik yang dimiliki oleh populasi tersebut, menurut Arikunto penentuan pengambilan sampel apabila kurang dari 100 lebih baik diambil semua hingga penelitiannya merupakan penelitian populasi. Jika jumlah subjeknya besar dapat diambil antara $10-15 \%$ atau 20-55\%.Populasi dalam penelitian ini adalah seluruh karyawan PT. Uniplastindo Interbuana Pandaan yang berjumlah 110 karyawan, sampel yang diambil dari keseluruhan karyawan adalah sekitar 40 karyawan bagian produksi. Metode sampel yang diambil adalah kuesioner yang disebarkan kepada karyawan PT. Uniplastindo Interbuana Pandaan bagian produksi. 


\section{Teknik Pengumpulan Data}

Pengumpulan data menurut Nazir (2009) adalah yang prosedur sistematis dan standar untuk memperoleh data yang diperlukan. Selalu ada hubungan antara metode pengumpulan data dengan masalah penelitian yang ingin dipecahkan. Terdapat beberapa metode dalam pengumpulan data penelitian, berikut ini terdapat dua cara yang peneliti lakukan untuk mengumpulkan berbagai informasi yang diperlukan peneliti, diantaranya adalah :

\section{1) Kuesioner}

Kuisioner merupakan instrumen untuk pengumpulan data, dimana partisipan atau responden mengisi pertanyaan atau pernyataan yang diberikan oleh peneliti. Peneliti dapat menggunakan kuisioner untuk memperoleh data yang terkaitdengan pemikiran, perasaan, sikap, kepercayaan, nilai, persepsi, kepribadian dan perilaku dari responden. Skala Likert digunakan untuk mengukur sikap, pendapat dan persepsi seseorang atau sekelompok orang tentang fenomena sosial (Sugiyono, 2013). Penelitian ini mengunakan sejumlah pernyataan dengan skala 5 (1-5) yang menunjukkan setuju, ragu atau tidak setuju terhadap pernyataan tersebut, kriteria jawaban sebagai berikut:

\section{Skala Likert}

Tabel 1. Skala Pengukuran

\begin{tabular}{|c|c|c|}
\hline \multicolumn{2}{|c|}{ Kriteria Jawaban } & Skor \\
\hline Sangat Setuju & SS & 5 \\
\hline Setuju & S & 4 \\
\hline Netral & N & 3 \\
\hline Tidak Setuju & TS & 2 \\
\hline Sangat Tidak Setuju & STS & 1 \\
\hline
\end{tabular}

Sumber : Dikutip dari Sugiyono, 2013

Teknik pengumpulan informasi yang dilakukan dengan cara menyusun data pernyataan yang akan diajukan pada responden dalam bentuk sampel dari sebuah populasi. Dalam penelitian ini, peneliti meneliti pengaruh gaji dan insentif terhadap kinerja karyawan bagian produksidi PT. Uniplastindo Interbuana Pandaan. Teknik yangdigunakan untuk mengumpulkan data primer dari responden dikelola dalam penelitian ini.

\section{2) Kepustakaan}

Kegiatan mengumpulkan bahan-bahan yang berkaitan dengan penelitianyang berasal dari jurnal ilmiah, literatur serta publikasilain yang layak dijadikan sumber penelitian.Teknik ini mengumpulkan teori-teori yang ada dalam literatur, sehingga memudahkan peneliti untuk mencari masalah dengan teori yang ada dan digunakan.

\section{Teknik Analisis Data Uji Validitas dan Rehabilitas}


1) Uji Validitas

Uji validitas ini digunakan sebelum kuesioner disebarkan kepada obyek penelitian untuk mengukur tingkat keakuratan sebuah instrumen penelitian.Jika $r$ hitung $>r$ tabel maka instrumen atau pernyataan memiliki korelasi terhadap skor total dinyatakan valid. Adapun metode yang digunakan pada uji validitas ini mengunakan Pearson Corelation, dimana dikatakan valid jika nilai signifikan $<\alpha(0,05)$.

2) Uji Reliabilitas

Uji reliabilitas data digunakan penyebaran kepada responden sudah dapat dipercaya. Suatu instrumen dikatakan reliable apabila jawaban seseorang (responden) terhadap pernyataan yang diajukan konsisten atau stabil. Metode yang digunakan untuk menguji reliabilitas kuesioner dalam penelitian ini adalah mengunakan rumus Alpha Cronbach, dimana dikatakan reliabel jika Alpha Cronbach $>0,6$.

\section{Analisis Regresi Linier Berganda}

Analisis regresi linier berganda digunakan untuk mengetahui pengaruh antar variabel bebas $(X)$ dengan variable terikat $(Y)$, yaitu pengaruh variabel Gaji $(X 1)$ dan Insentif (X2) terhadap Kinerja Karyawan (Y) bagian produksi PT. Uniplastindo Interbuana Pandaan. Analisis regresi linier berganda menurut Arikunto (2009:309) adalah :

$$
\begin{array}{ll}
\mathrm{Y}=\mathrm{a}+\mathrm{b} 1 \mathrm{X} 1+\mathrm{b} 2 \mathrm{X} 2+\mathrm{e} \\
\mathrm{Y} & =\text { Kinerja Karyawan di PT.Uniplastindo Interbuana Pandaan } \\
\mathrm{X} 1 & =\text { Gaji } \\
\mathrm{X} 2 & =\text { Insentif } \\
\mathrm{a} & =\text { Nilai konstanta } \\
\mathrm{b} 1, \mathrm{~b} 2 & =\text { Koefesien perubahan X1, X2 terhadap } \mathrm{Y} \\
\mathrm{e} & =\text { Tingkat kesalahan }
\end{array}
$$

\section{Pengujian Hipotesis}

a. Uji $F$

Uji F bertujuan untuk menunjukan apakah semua variabel independen yang dimasukan ke dalam model secara simultan atau bersama-sama mempunyai pengaruh pengujian.

b. Ujit

Uji t digunakan untuk menguji untuk apakah semua variabel bebas yang ada pada model secara individual mempunyai pengaruh yang signifikan pada model secara individual. Jika hasil perhitungan menunjukkan bahwa nilai signifikan (sig) < alpha 0,05 maka Ha diterima dan Ho ditolak. Sedangkan jika signifikan (sig) > alpha 0,05 maka Ha ditolak dan Ho diterima. 


\section{HASIL DAN PEMBAHASAN}

\section{A. Uji Validitas}

Berikut ini hasil uji validitas untuk setiap item pernyataan berdasarkan pengolahan data dengan menggunakan SPSS 25 for Windows :

Tabel 2. Hasil Uji Validitas Variabel Gaji

\begin{tabular}{|c|c|c|c|}
\hline Item & $r$ hitung & $r$ tabel & Keterangan \\
\hline 1 & 0,829 & 0,304 & Valid \\
\hline 2 & 0,785 & 0,304 & Valid \\
\hline 3 & 0,765 & 0,304 & Valid \\
\hline 4 & 0,585 & 0,304 & Valid \\
\hline 5 & 0,712 & 0,304 & Valid \\
\hline 6 & 0,774 & 0,304 & Valid \\
\hline
\end{tabular}

Sumber : Data primer diolah, 2020

Tabel 3. Hasil Uji ValiditasVariabel Insentif

\begin{tabular}{|c|c|c|c|}
\hline Item & $r$ hitung & $r$ tabel & Keterangan \\
\hline 1 & 0,755 & 0,304 & Valid \\
\hline 2 & 0,733 & 0,304 & Valid \\
\hline 3 & 0,732 & 0,304 & Valid \\
\hline 4 & 0,789 & 0,304 & Valid \\
\hline 5 & 0,649 & 0,304 & Valid \\
\hline 6 & 0,630 & 0,304 & Valid \\
\hline
\end{tabular}

Sumber : Data primer diolah, 2020

Tabel 4. Hasil Uji ValiditasVariabel Kinerja Karyawan

\begin{tabular}{|c|c|c|c|}
\hline Item & $r$ hitung & $r$ tabel & Keterangan \\
\hline 1 & 0,703 & 0,304 & Valid \\
\hline 2 & 0,642 & 0,304 & Valid \\
\hline 3 & 0,830 & 0,304 & Valid \\
\hline 4 & 0,736 & 0,304 & Valid \\
\hline 5 & 0,425 & 0,304 & Valid \\
\hline 6 & 0,609 & 0,304 & Valid \\
\hline 7 & 0,648 & 0,304 & Valid \\
\hline 8 & 0,711 & 0,304 & Valid \\
\hline
\end{tabular}

Sumber : Data primer diolah, 2020 
Berdasarkan hasil uji validitas diperoleh nilai $r$ hitung dari variabel gaji, insentif dan kinerja karyawan lebih besar dari nilai $r$ tabel sebesar 0,304. Maka 20 item pernyataan tersebut dinyatakan valid terbukti.

\section{B. Uji Reliabilitas}

Tabel 5. Hasil Uji Reliabilitas

\begin{tabular}{|l|c|c|}
\hline \multicolumn{1}{|c|}{ Variabel } & Nilai Reliabilitas & Keterangan \\
\hline Gaji & 0,904 & Reliabel \\
\hline Insentif & 0,892 & Reliabel \\
\hline KinerjaKaryawan & 0,885 & Reliabel \\
\hline
\end{tabular}

Sumber : Data primer diolah, 2020

Variabel dapat dikatakan reliabel atau tidak adalah $\alpha$ (alpha). Jika $\alpha \geq 0,6$ maka item pernyataan tersebut dikatakan reliabel, sedangkan dikatakan tidak reliabel jika nilai $\alpha$ tidak $\geq 0,6$. Dalam penelitian ini teknik pengujian reliabilitas adalah dengan menggunakan nilai koefisien cronbach alpha dan untuk mengetahui nilai reliabilitas, maka peneliti menggunakan SPSS 25 for Windows. Berdasarkan hasil uji reliabilitas diperoleh nilai reliabel gaji 0,904, insentif 0,892 dan kinerja karyawan 0,885.Maka 20 item pernyataan tersebut dinyatakan reliabel terbukti.

\section{Uji F (Simultan)}

Tabel 6. Hasil Uji F (Simultan)

\begin{tabular}{|c|c|c|c|c|c|}
\hline \multicolumn{6}{|c|}{ ANOVA $^{a}$} \\
\hline Model & Sum of Squares & $\mathrm{df}$ & Mean Square & $\mathrm{F}$ & Sig. \\
\hline Regression & 257.245 & 2 & 128.623 & 15.394 & $.000^{\mathrm{b}}$ \\
\hline Residual & 309.155 & 37 & 8.356 & & \\
\hline Total & 566.400 & 39 & & & \\
\hline Denond & rval & & & & \\
\hline
\end{tabular}

Sumber : Data primer diolah, 2020

Berdasarkan hasil uji $F$ (Simultan), diketahui nilai sig. $F$ hitung sebesar 0,00 karena nilai signifikansi $\mathrm{F}$ kurang dari 0,05 maka model analisis regresi adalah signifikan. Hal ini berarti HO ditolak dan H1 diterima, sehingga dapat disimpulkan bahwa variabel bebas gaji dan insentif secara simultan berpengaruh terhadap kinerja karyawan bagian produksi PT. Uniplastindo Interbuana Pandaan. 


\section{Uji t (Parsial)}

\section{Tabel 7. Hasil Uji t (Parsial)}

\begin{tabular}{|c|c|c|c|c|c|c|c|}
\hline \multirow[b]{3}{*}{ Model } & \multicolumn{5}{|c|}{ Coefficients $^{a}$} & & \\
\hline & \multicolumn{2}{|c|}{$\begin{array}{l}\text { Unstandardized } \\
\text { Coefficients }\end{array}$} & \multirow{2}{*}{$\begin{array}{c}\text { Standardized } \\
\text { Coefficients } \\
\text { Beta }\end{array}$} & \multirow[b]{2}{*}{$\mathrm{t}$} & \multirow[b]{2}{*}{ Sig. } & \multicolumn{2}{|c|}{ Collinearity Statistics } \\
\hline & B & Std. Error & & & & Tolerance & VIF \\
\hline 1 (Constant) & 10.928 & 3.990 & & 2.739 & .009 & & \\
\hline Gaji & .423 & .170 & .368 & 2.483 & .018 & .673 & 1.485 \\
\hline Insentif & .433 & .163 & .393 & 2.652 & .012 & .673 & 1.485 \\
\hline
\end{tabular}

a. Dependent Variable: KinerjaKaryawan

Sumber : Data primer diolah, 2020

Berdasarkan hasil uji $\mathrm{t}$ menjelaskan bahwa variabel gaji dan insentif berpengaruh signifikan terhadap variabel kinerja karyawan, karena gaji signifikan 0,018 $<0,05$ dan insentif signifikan 0,012 <0,05. Maka hasil uji t dinyatakan signifikan.

\section{Pengaruh Dominan}

Berdasarkan tabel 5 tersebut, maka variabel insentif yang paling dominan berpengaruh terhadap kinerja karyawan. Hal ini ditunjukkan dengan nilai Standardized Coefficients Beta variabel insentif lebih besar dibandingkan variabel gaji. Variabel insentifdari indikator antara lain : kinerja, lama bekerja, senioritas, kebutuhan, keadilan dan kelayakan, evaluasi jabatan.

\section{SIMPULAN}

Berdasarkan peneliti lakukan pada penelitian ini, dapat diperoleh kesimpulan sebagai berikut :

1) Berdasarkan dari hasil uji $F$ (Simultan), diketahui nilai sig. $F$ hitung sebesar 0,00 karena nilai signifikansi $F$ kurang dari 0,05 maka model analisis regresi adalah signifikan. Sehingga dapat disimpulkan bahwa variabel bebas gajidan insentif secara simultan berpengaruh terhadap kinerja karyawan bagian produksi PT. Uniplastindo Interbuana Pandaan.

2) Hasil uji t menjelaskan,bahwa variabel gaji dan insentif berpengaruh signifikan terhadap variabel kinerja karyawan, karena gaji signifikan $0,018<0,05$ dan insentif signifikan 0,012 <0,05.Maka hasil uji t dinyatakan signifikan.

3) Variabel insentif yang paling dominan berpengaruh terhadap kinerja karyawan. Hal ini ditunjukkan dengan nilai Standardized Coefficients Beta variabel insentif lebih besar dibandingkan variabel gaji. Dipengaruhi indikator antara lain : kinerja, lama bekerja, senioritas, kebutuhan, keadilan dan kelayakan, evaluasi jabatan. 


\section{SARAN}

A. Bagi Perusahaan

1) Berdasarkan dari penelitian ini, variabel gaji, insentif dan kinerja karyawan hasil kuesioner dari responden rata-rata cukup baik. Dalam hal ini perusahaan perlu meningkatkan lebih baik lagi untuk kinerja karyawan bagian produksi PT. Uniplastindo Interbuana Pandaan.

2) PT. Uniplastindo Interbuana Pandaan harus konsisten dan perlu dipertahankan pada variabel insentif yang dipengaruhi indikator kinerja, lama bekerja, senioritas, kebutuhan, keadilan dan kelayakan, evaluasi jabatan.

B. Bagi Peneliti

Peneliti yang akan meneliti pada variabel gaji dan insentif berpengaruh terhadap kinerja karyawan bagian produksi PT. Uniplastindo Interbuana Pandaan, bisa lebih mengembangkan dalam hasil penelitian ini.

\section{DAFTAR PUSTAKA}

Arikunto, Suharsimi. 2006. Prosedur Penelitian Suatu Tinjauan Praktek. Yogyakarta: BPFE.

Arikunto, Suharsimi. 2009. Manajemen Penelitian. Jakarta: PT. Rineka Cipta.

Diviani Gracetiara Mera. 2015. Analisis Pengaruh insentif Terhadap Kepuasan Kerja dan Kinerja Karyawan Sebagai Variable Mediasi. Jepara: Universitas Diponegoro.

Ferdinand. 2006. Metode Penelitian Manajemen. Semarang: Universitas Diponegoro.

Handoko, T. Hani. 2008. Manajemen Personalia Dan Sumber Daya Manusia. Yogjakarta: Liberty.

Hasan, M. Iqbal. 2002. Pokok-pokok Materi Metodologi Penelitian dan Aplikasinya. Bogor: Ghalia Indonesia.

Hasibuan, Malayu. 2012. Manajemen Sumber Daya Manusia. Jakarta: PT. Bumi Aksara.

Kadarisman, M. 2012. Manajemen Pengembangan Sumber Daya Manusia. Jakarta: Raja Grafindo Indonesia.

Kurniawati, Tursina. 2013. Pengaruh Proses Rekrutmen, Seleksi dan Gaji Terhadap Kinerja Karyawan Pada PT. Bank Syariah Mandiri Cabang Yogjakarta. Yogjakarta.

Mangkunegar, Anwar Prabu. 2008. Manajemen Sumber Daya Manusia. Bandung: PT. Remaja Rosdakarya.

Mangkunegara, Anwar prabu. 2012. Evaluasi Kinerja Sumber Daya Manusia. Bandung: PT. Refika Aditama.

Moeheriono. 2009. Pengukuran Kinerja Berbasis Kompetensi. Bogor: Ghalia.

Mulyadi. 2013. Manajemen Sumer Daya Manusia. Bandung: Ghalia Indonesia.

Nawawi. 2011. Manajmen Sumber Daya Manusia. Yogjakarta: Gajahmada University Press. 
Nazir, Moh. Ph. D. 2009. Metode Penelitian. Jakarta: Ghalia Indonesia

Prawirosentono, Suyadi. 2008. Manajemen Sumber Daya Manusia Kebijakan KinerjaKaryawan. Yogyakarta: BPFE.

Riani, Asri Laksmi. 2013. Manajemen Sumber Daya Manusia Masa Kini. Yogjakarta: Graha Ilmu.

Rivai, Veithzal. 2011. Manajemen Sumber Daya Manusia Untuk Perusahaan Dari Teori ke Praktek. Jakarta: PT. Raja Grafindo Persada.

Samsudin, Sadili. 2010. Manajemen Sumber Daya Manusia. Bandung: PT. Pustaka Setia.

Sastrohadiwiryo, Siswanto. 2010. Manajemen Tenaga Kerja Indonesia. Bandung: PT. Bumi Aksara.

Siagian, Sundang P. 2010. Manajemen Sumber Daya Manusia. Jakarta: PT. Bumi Aksara.

Sirait, Justine. T. 2006. Memahami Aspek-aspek Pengelolaan Sumber Daya Manusia Dalam Organisasi. Jakarta: Gramedia Widya Sarana Indonesia.

Subianto, Marinus. 2016. Pengaruh gaji dan Insentif Terhadap Kinerja Karyawan pada PT. Serba Mulia Auto di Kabupaten Kutai Bali. Samarinda: Universitas Mulawarman.

Sugiono. 2008. Metode Penelitian Kuantitatif dan R\&D. Bandung: ALFABETA.

Sugiono. 2013. Statistika Untuk Penelitian. Bandung: CV. ALFABETA.

Sulistiyani, Rosidah. 2009. Manajemen Sumber Daya Manusia. Yogjakarta: Graha Ilmu.

Wibowo. 2014. Manajemen Kinerja. Jakarta: Rajawali Pers.

Wungu dan Brotoharjoso. 2003. Tingkatkan Kinerja Perusahaan Dengan Merit System. Jakarta: PT. Raja Grafindo Persada.

Yani, N. 2012. Manajemen Sumber Daya Manusia. Jakarta: Mitra Wacana Media. 